ÉGYPTE monde arabe

\section{Égypte/Monde arabe}

9 | 2012

Gouvernance locale dans le monde arabe et en

Méditerranée : Quel rôle pour les femmes?

\title{
Political participation of Jordanian Women
}

La participation politique des femmes de Jordanie

Jamal Al Shalabi and Tareq Al-Assad

\section{(2) OpenEdition}

Journals

Electronic version

URL: https://journals.openedition.org/ema/3033

DOI: $10.4000 /$ ema.3033

ISSN: 2090-7273

Publisher

CEDEJ - Centre d'études et de documentation économiques juridiques et sociales

Printed version

Date of publication: 1 January 2012

Number of pages: $211-230$

ISBN: 2 905838-48-5

ISSN: 1110-5097

Electronic reference

Jamal Al Shalabi and Tareq Al-Assad, "Political participation of Jordanian Women", Égypte/Monde arabe [Online], 9 | 2012, Online since 31 December 2012, connection on 07 July 2022. URL: http:// journals.openedition.org/ema/3033 ; DOI: https://doi.org/10.4000/ema.3033 
Jamal Al Shalabi \& Tareq Al-Assad

\section{RÉSUMÉ / ABSTRACT}

\section{LA PARTICIPATION POLITIQUE DES FEMMES DE JORDANIE}

Cet article se propose d'étudier le rôle politique des femmes en Jordanie et d'analyser ce rôle à travers diverses problématiques juridiques, en particulier la constitution de 1952, la Charte nationale de 1990, et les conventions internationales sur les femmes, en montrant l'impact (positivement ou négativement) des changements politiques, tels que celui mis en œuvre par la " démocratisation » qui a débuté en 1989. Bien que les femmes aient occupé des postes de "ministres», de dirigeants de partis politiques ou des fonctions dans le système judiciaire, à différentes époques, les problèmes et les obstacles qu'elles rencontrent ainsi que leur rôle dans la vie politique, soumis aux traditions et aux contraintes des lois électorales, seront mis en évidence dans cette étude.

\section{POLITICAL PARTICIPATION OF JORDANIAN WOMEN}

This article aims to study the political role of women in Jordan and to analyse this role through various legal laws, especially the constitution of 1952, the National Charter of 1990, and international conventions on women by showing the impact (positively or negatively) of political changes, such as the "democratisation" that began in 1989 on this role. Although women have been assigned as 'ministers' and leaders of political parties and the judicial system, in different periods of time, the problems and obstacles faced by Jordanian women and their role in political life still exist, such as: traditions and electoral laws are still on the line, which needs to be highlighted in this study.

JAMAL AL SHALABI Professeur agrégé en sciences politiques à I'Université Hachémite. II est actuellement le vice-doyen de la Faculté des lettres. II a obtenu son doctorat à l'université de Paris II, membre du comité de suivi de I'IFPO. II a reçu « le prix de Sharjah pour la culture arabe » de I'Unesco, en 2006. 
TAREQ AL-ASSAD Directeur du département de sciences humaines et sociales à l'Université Hachémite, il est l'auteur de plusieurs études et ouvrages sur les droits de l'homme et la pensée islamique.

JAMAL AL SHALABI is Associate Professor in Political Science at the Hashemite University, and he is now the vice dean of the faculty of arts. He holds a doctorate in political science from the University of Paris II. He has been awarded the Arab Culture award by UNESCO in 2006.

TAREQ AL-ASSAD is Head of the Human and Social Sciences Department at the Hashemite University. He is the author of several books, including one on human rights and Islamic thought. 
Jamal Al Shalabi \& Tareq Al-Assad

\section{POLITICAL PARTICIPATION OF JORDANIAN WOMEN}

\section{INTRODUCTION}

$\mathrm{F}$

or the first time since the establishment of the Emirate of Trans Jordan in 1921, the number of women in the $16^{\text {th }}$ Jordanian legislative assembly, which was elected in December 2010, reached 13 out of a total of 120 members, one by direct election and the rest by virtue of the Women's Quota Law enacted in 2010.

This high women's presence leads to the belief that there is a "higher policy" by the state, that seeks to propel women forward to participate in decision-making at all levels, legislative, executive, and judicial. This "higher policy" is interpreted into reality through the "quota policy" that opened the door for Jordanian women to enter parliament in force by allocating six seats for women in the 2007 elections, and raising the number of allocated seats to 12 in the Temporary Election Law Number 9 for the Year 2010'.

In truth, the Jordanian leadership, particularly the King and Queen, have a vision that women's political participation is considered a clear indicator of progress for the Jordanian state and its international image $^{2}$, a point that receives special attention in Jordan, particularly in the context of globalization and the communication revolution that has transformed the world into a "village" with human rights, including women's rights, being among its main features.

To understand the experience of Jordanian women's political participation, we shall first highlight the role of legislation that defines the

1. Owemer Walid, "Political rights of Jordanian women between the law and reality", 27 July 2010, Amman website: http://www.ammonnews.net/ article.aspx?articleNO=65890.

2. Al Shalabi Jamal, "Globalization and its impact on Media \& Education in Jordan", Arab Institute for Studies and Publication, Beirut, 2009, p. 5. 
parameters of this participation; second, we shall address the development of this participation in reality, through the progress of the Jordanian state, particularly in the context of Jordan's democratic transformation in $1989^{3}$ and the social, political and cultural hurdles that faced women's participation.

\section{WOMEN'S RIGHTS IN THE LAW}

Jordanian laws paid special attention to the political rights of women and the role that they could play through attaining high positions in the Jordanian state. This is made clear by the "battery" of legal foundations in force in Jordan, mainly the Constitution of $1952^{4}$, the National Charter of 1990, as well as Jordan's commitment to international agreements related to women such as the Convention on the Elimination of Discrimination against Women (CEDAW) Agreement which Jordan signed in 1980 and ratified in $1992^{5}$. Therefore, we shall highlight the legal provisions that regulate the Jordanian state's vision of women and women's political participation through different laws.

The Jordanian Constitution of 1952 considered men and women equal in rights and duties. Most important is the provision of Article 6, which states that: "Jordanians shall be equal before the law. There shall be no discrimination between them as regards to their rights and duties on grounds of race, language or religion" ${ }^{\prime 6}$. The Constitution reaffirmed this in Article 22, which states that: "Every Jordanian shall be entitled to be appointed to public offices under such conditions as are prescribed by law or regulations"

3. Al Shalabi Jamal, "The Movement towards Democracy and Freedom of the Press in Jordan", (in Arabic), The Emirates Center for Strategic Studies and Research, Abu Dhabi, United Arab Emirates, 2000, p. 7.

4. Twal Malek, "La Constitution jordanienne de 1952 et ses amendement: Un equilibre évolutif entre les pouvoirs, une garantie et une protection des libertés fondamentales des droits politiques", Centre d'études des droits du monde arabe, Université Saint-Joseph de Beyrouth, 2006, p. 10. (Voir également http://www.cedroma.usj.edu.lb/pdf/cpayar/twal.pdf.)

5. Al Shalabi Jamal, "The political and civil rights of women and children in the Agreements of Children's Rights and CEDAW", UNICEF, Amman, 2000, p. 3.

6. See the "The Jordanian Constitution and all its amendments" in El-Dajani Mohamed \& Munther El-Dajani, "Introduction to the Jordanian Political System", Palomino Press, Amman, 1993, p. 454.

7. Ibid, p. 455. 
The National Charter $^{8}$ in 1990 also affirmed a number of rights for Jordanian women, including the provision of Article 8, which states clearly that: "Jordanian men and women are equal under the law. There shall be no distinction between them in rights and obligations regardless of difference in race, language or religion. They shall exercise their constitutional rights and uphold the higher interest of the state $^{\prime \prime}$. Chapter 2, Third Article, entitled "Guarantees of the Democratic Approach", Section 4, states that: "Attaining equality, justice and equal opportunities for all citizens, male and female, without discrimination." The Fourth Article of the Charter affirmed that: "Jordanians enjoy the right to establish and belong to political parties and groupings, provided that their objectives are legitimate, their methods are peaceful and their statutes do not violate the provisions of the Constitution"10.

In Chapter Five Article 6, the Charter states that: "Women are men's partners and equals in contributing to the growth and development of Jordanian society. This requires an affirmation of women's constitutional and legal right to equality, guidance, training and employment as a means of enabling them to play their proper role in the growth and development of society"11.

For this reason, other Jordanian laws came in harmony with the constitution which aims to establish women's equality with men in all rights. Many laws were amended in favor of women, such as the Election Law. Although the Jordanian Constitution did not differentiate between men and women in the practice of their rights, Jordanian women were deprived of practicing their rights in equality with men

8. The National Charter: It is the document issued in the aftermath of the formation of a royal committee on April 9, 1990, chaired by former prime minister Ahmad Obeidat, and with the participation of 60 members representing the entire Jordanian political spectrum from the "Badia" desert regions, the city and the countryside, and the political, religious and gender orientations, both male and female. The aim, as outlined in his speech delivered during meeting this committee was: "The task before them is to formulate a national covenant, which would constitute a point of departure over which would concur the people in all its segments with a view to approaching an era of political pluralism." This covenant is considered a social contract between ruler and ruled, and hence it could be said that this national charter and the Constitution together constitute the main ramparts and points of reference in the Jordanian political arena. See http://webcache.googleusercontent.com/ search?q=cache:QnDuURWCiec):www.parobserver.org.

9. El-Dajani Mohamed \& Munther El-Dajani, op.cit., p. 485.

10. Ibid, p. 488.

11. Ibid, p. 495. 
in the electoral process. This state of affairs lasted until the definition of the term "Jordanian" in Article 2 of the Election Law No. 24 for the Year 1960 was redefined to become "every person, male or female" by means of Amendment 8 for the Year 1974 ${ }^{12}$. Furthermore, women were allowed to stand for election and to vote for the first time in legislative assemblies after they had been excluded from such participation. This law was followed by the 1982 law, which in turn opened the door for Jordanian women to stand for election in municipal councils as well ${ }^{13}$.

The most recent amendment to the Election Law for the Chamber of Deputies for the Year 2001 can also be considered positive and in favor of women, because it reduced the voting age to 18 years, which raised the proportion of voting women who are expected to contribute to political and parliamentary life in Jordan. Raising the number of parliamentary seats in 2003 to 110 also contributed to a number of seats going to women, by allocating a "women's quota" through adding 6 seats to the total number of parliamentary seats allocated to electoral constituencies, which would otherwise lead to the election of 104 deputies.

Actually, Jordan is one of the first Arab states which adopted the quota system for the first time through amending the parliamentary electoral law in 2003. Applying the quota system evolved by the promulgation of a new provisional electoral law Number 9 of 2010, pursuant to which 12 seats on a quota basis were allocated to women to be contested by women who did not win parliamentary seats allocated to electoral districts in which they ran in the 12 governorates, in the 3 Bedouin electoral districts. The quota system was applied in Jordan in the following manner:

1. After counting the votes and announcing the final results of the elections in all the electoral subdistricts a table is drawn up containing the number of votes obtained by the female candidates who did not win any of the parliamentary seats allocated for electoral districts.

2. A list of the number of voters in each subdistrict is prepared at the level of the entire country.

3. The number of votes that each female candidate won is calculated from the total number of voters in the subdistrict in which she ran. 4. Comparisons shall be made between the ratios obtained by all the women in the Kingdom.

12. Khozai Nadereh, "Women's right to membership of elected bodies", Master's thesis, Legal Studies Department, Al Beit University, Mafraq, 2005, p. 31.

13. Owemer Walid, op.cit. 
5. The names of the winners of the additional seats allocated for women at the level of the Kingdom shall be determined in comparison between those ratios, and the winners of these seats are the candidates who got the highest percentages in all the electoral subdistricts, provided that the winners of these seats allocated for women in each governorate and in any one of the Badia electoral districts do not exceed one winner; in other words, the highest percentage will be calculated for each of the 12 governorates and each of the 3 districts of the Bedouins; that is, we will have 15 women from the Kingdom qualified to win the additional seats, and thence the additional seats will be allocated to the highest 12 percent from the 15 that have qualified ${ }^{14}$.

In fact, the quota system caused considerable controversy in Jordanian political and legal circles; those who oppose the system argue that allocating seats for women in parliament contradicts democracy, because election should be on the basis of nationality irrespective of exceptions and special cases, and that women should be elected to parliament through their own force so that their ability would be recognized $^{15}$. Supporters of the quota system, on the other hand, see that this system achieves more comprehensive representation of all segments of society, because parliament should represent all sectors of society; and since there are many hurdles that prevent women from being elected to parliament and that are not easy to overcome, the quota should be introduced for a transitional period ${ }^{16}$.

In truth, the purpose of the quota is not merely to help women reach parliament, but also to encourage discussion of women's issues and ensure their participation in the process of comprehensive development, given that the quota system has been in force in Jordan for more than half a century, with a parliamentary quota for Bedouins, another for Christians, and a third for Jordanians of Circassian origin; i.e., there is a social quota, a religious quota, and an ethnic quota ${ }^{17}$. At any rate, it is clear from looking at parliaments all over the world that women constitute on average $18.4 \%$ of seats. In Sweden the ratio is $74.3 \%$, and Rwanda came in second place with $56.3 \%$ owing to the quota system ${ }^{18}$.

14. http://www.jordanelection2010.com/pages/index/40.

15. Habashneh Khadija, "Women's quota and democratic progress" in Issues of Civil Society, Al Urdun Al Jadid Center, Amman, 2004, p. 2.

16. Ibid, p. 3.

17. Owemer Walid, op.cit.

18. Sparre Charlotta, "On International Women's Day", Jordan Times, Amman, 8 March, 2011. 
In addition to these national legislations, there is a total Jordanian commitment to implementing the principles of the "Universal Declaration of Human Rights" of 1948, the Convention on the Political Rights of Women (1952) which Jordan joined in 1992, the two international covenants on human rights for the Year 1966, the Convention for the Elimination of all Forms of Discrimination against Women (CEDAW) of 1979, which Jordan signed in 1980 and ratified in $1992^{19}$.

\section{POLITICAL PARTICIPATION OF JORDANIAN WOMEN}

The status of women and their political participation varies in Jordan over time due to a number of political, economic, and social transformations on the national, regional, and international levels. The democratic transformation ${ }^{20}$ that Jordan underwent in 1989 - for instance, as a result of the collapse of the Eastern Bloc, the fall of the Berlin Wall, and the dominance of the USA over world affairs -, had a major effect on raising political participation in comparison with the past. Therefore, we shall seek to compare the status of Jordanian women politically and professionally, before and since the democratic transformation of 1989, and until the present.

\section{First: Women: A long struggle for political participation}

The political circumstances that Jordan lived through at the end of the forties of the past century had a major effect on the political status and political participation of women, who had no clear political activity. The reason why women refrained or were alienated from active political participation derives from a number of conditions that were objective in those days: education of women was weak; economic conditions were difficult; the tribal nature of Jordanian society refused to give a political role for women; and that period laid the overall foundations of Jordanian

19. «Jordan had reservations regarding Article 9/2 of this agreement, concerning equal rights of women and men to give their nationality to their children and Article 15/4 that gives women equal rights as men in laws related to individual freedom, the freedom to choose their place of residence and domicile and other articles; but in doing so, Jordan was not seeking to circumvent women's rights». See Mohamed Khair lyadat "Towards the political empowerment of Jordanian women", United Nations Development Fund for Women (UNIFEM), Amman, 2006, p. 9.

20. Al Shalabi Jamal, "The Movement towards Democracy and Freedom of the Press in Jordan", op.cit., p. 30. 
political activity, without special attention being paid to women. These conditions combined to focus the then nascent Jordanian women's movement on improving health and educational conditions and providing social care without looking at the political dimension ${ }^{21}$.

As a result there emerged, during this period, a number of women's organizations such as the "Organization of Social Women's Welfare" in 1944 and the "Women's Union Association" of 1945, which represented the overall framework for women's action. The war of 1948 and the subsequent Palestinian migration to Jordan mobilized women's efforts and focused them on welfare organizations ${ }^{22}$.

During the fifties of the past century, women's participation in political action emerged through their participation in the activities of political parties, giving speeches, distributing publications, and organizing demonstrations in order to gain political rights equal to men and calling for their right to vote. These attempts led to a draft amendment of the election law, which was approved by the Council of Ministers in 1955. The amendment gave women who had completed at least primary education the right to vote, but withheld it from illiterate women, although illiterate men enjoyed this right, which constituted discrimination against women. The question of political participation was raised through the establishment of the "Arab Women's Union" of 1954, which focused on raising women's political awareness, eliminating illiteracy, and preparing women to practice their rights. The Union was dissolved in 1957 upon the declaration of martial law, after Jordan experienced an attempted coup d'état organized by some Free Officers in the Jordanian army ${ }^{23}$.

During the sixties and seventies, political mobilization and action by Jordanian women became prominent, coinciding with the Arab Israeli wars of 1967, Al Karameh Battle in 1968, and the war of 1973. Women's role became prominent in mobilization that included cities, villages, Palestinian refugee camps in Jordan, and in organizing women's demonstrations in which thousands of women participated.

In 1974, women were given the right to stand for election and to vote. The beginning of the eighties saw the women's movement thrive

21. Zash Amal, "Jordanian women and their intellectual output over half a century", Greater Amman Municipality, Amman, 2003, p. 42.

22. Ktishat Yasser, "The role of Jordanian women in political participation: the present and the future, between hurdles and ambitions", Master's thesis, Al Beit University, Mafraq, 2004, p. 7.

23. Al Shalabi Jamal, "The Muslim Brothers in Jordan: From Alliance to Divergence", Stratégies islamistes, Confluence Méditerranée, L'Harmatttan, n 76, Hiver 2010-2011, Paris, p. 121. 
with the organization of effective women's organizations that had national objectives such as "The League of Democratic Jordanian Women" in 1983, and the "Arab Women's League" in 1985; this coincided with international interest in women and their rights and the opening up of the Jordanian women's movement to its outside environment. As a result, a number of organizations were formed such as The Women's Union in Jordan (WUJ) in 1974, which became the Jordanian Women's Union (JWU) in $1981^{24}$. It should be noted here that, in addition to the ban on political parties in 1957, the loss of the West Bank to Israel in 1967 led to the declaration of a state of emergency, which eliminated any prospects of political party action, whether for men or women; Jordan became a closed zone for political action!

To fill this political vacuum, the Late King Hussein established the National Consultative Council in 1978, which comprised 9 women out of a total of 190 appointed members for the period 1978 to 1982. In 1979, Ms. In'am Al Mufti was appointed Minister of Social Development, and for the first time, a woman was appointed to the Amman Municipal Council in 1980. In 1982, the Municipalities Law was promulgated, giving women the right to vote and to stand for election to municipal councils. Women's progress and participation in political action continued with the appointment of Ms. Laila Sharaf as Minister of Information in $1984^{25}$.

Based on the above, it would be fair to say that the period before 1989 was an important phase for women's political participation, although it was not political participation per se, but participation which overlapped with political action, such as education, demonstrations, establishing welfare organizations and the like. This also does not deny that these social efforts pushed the decision-maker to take into consideration the demands of women, who constitute not only half of society, but also an important part of it; this is an important issue for the comprehensive development that the regime seeks.

24. Abu Al Samen Mai, "Jordanian Women and Political Participation", the National Conference for Political Development and Jordanian Women, University of Science and Technology, 2004, p. 2. See also http://www.jwu. itgo.com/bg.htm.

25. Khader Asma, "Women and Democracy", at the conference "Jordanian democratic process, reality and prospects", prepared by Hani Hourani, Amman, Sinbad Publishing House, 1996, p. 235. 


\section{Second: Women's political participation and the democratic transformation}

The period 1989 to 2010 saw a qualitative leap in women's participation in political life in Jordan, as voters and as candidates to the Legislature, and as political actors in the Executive and Judiciary and particularly in civil society organizations.

\section{The Legislature: The Senate and Chamber of Deputies}

At the Chamber of Deputies, women were able to exercise their right to vote and be elected for the first time in 1989. Twelve women stood out of 647 candidates who competed for 80 seats. Only $2 \%$ of the candidates were women, and none were supported by any political party or stream. No women were elected. In 1993, only three women stood out of 550 candidates, or $0.6 \%$ of the candidates. All those candidates, namely, Janet Al-Mufti, Nadia Bushnaq, and Toujan Faisal used to partake in the elections as independent candidates and without the support of a political party, albeit Toujan Faisal has nationalist leanings without any real belonging to any political party ${ }^{26}$.

For the first time, a woman was elected. She was Ms. Toujan Faisal, who won one of the three seats allocated for the Circassian minority. Ms. Faisal is considered an important example of women's participation in politics in Jordan not only because she won in the elections, but also because she proved that women are capable of having an independent and effective political discourse. Ms. Faisal says that her popularity was not due to her social demands, but her political discourse which her supporters understood and supported ${ }^{27}$. She described her career as a member of parliament in the following terms: "I defend a new style of parliamentary action that proposes solutions to political problems" ${ }^{\prime 28}$. Ms. Faisal's independence and courage in exposing cases of corruption and nepotism in Jordan aroused the enmity of conservatives and Islamists in parliament, but her sincere commitment to democracy and human rights, and her thorough knowledge of the teachings of Islam gained her the respect and support of a segment of society"29.

26. http://archive.electionsjo.com/ESubject/DefaultSub.asp?seid=99.

27. Abu-zayd Gehan, "A la quête du pouvoir politique - les femmes au parlement en Egypte, en Jordanie et au Liban", Etude de cas, p. 53. See www. idea.int/publications/wip/upload/chapter_02b-CS_Egypt.pdf.

28. Ibid.

29. Ibid. 
In 1997, 17 women stood out of 561 candidates, or 3\% of the total, but no women were elected. In the complementary elections of 2001, conducted upon the decease of a member of the $13^{\text {th }}$ Assembly, a woman was elected by the same assembly, though not in general elections. The elections of 2003 were conducted after the new election law had been promulgated in 2003, which stipulated that women should be present in parliament by introducing a "quota system". Six women were elected after the votes in all electoral constituencies had been counted. Consequently, six women, one of whom belonged to the Islamist stream, were elected through the quota system, constituting $5.5 \%$ of the assembly that comprised 110 deputies $^{30}$.

In the 2007 elections, the same scene was repeated as in 2003, with six women being elected through the quota system, but with the slight difference that one woman, Falak Al-Jamani was elected through competition and not through the quota.

In the legislative elections of 2010, women's participation reached $53 \%$ compared to $52 \%$ in the 2007 elections. In 2010, 142 women stood for election, including one woman, Reem Badran, the well known economist and daughter of former Prime Minister Mudar Badran, as well as 12 women who were elected through the quota ${ }^{31}$. It should be noted that women candidates received $6 \%$ of the votes in 2010, compared to $3.4 \%$ in $2007^{32}$.

30. Nasser Lamis, "Women and political development in official and civil reference documents", the Women and Political Development Conference, Amman, 2004, p. 8.

31. Le Monde, "Élections législatives en Jordanie sur fond de tensions", Paris, 9 novembre 2010.

32. http://www.sahafi.jo/nsart_info.php?id=6ebae66eea4362dec0855c18 6d264d5f2a7ba0ae. 
TABLE 1: DEVELOPMENT OF WOMEN'S PARTICIPATION IN THE LEGISLATURE ${ }^{33}$

\begin{tabular}{|l|r|r|l|l|}
\hline $\begin{array}{c}\text { Election } \\
\text { Year }\end{array}$ & $\begin{array}{c}\text { No. of } \\
\text { Women } \\
\text { candidates }\end{array}$ & $\begin{array}{c}\text { Total } \\
\text { No. of } \\
\text { candidates }\end{array}$ & $\begin{array}{c}\text { Ratio of } \\
\text { Women } \\
\text { Candidates } \\
\text { to Total }\end{array}$ & Winners \\
\hline 2010 & 134 & 763 & $17.5 \%$ & 12 Quota +1 \\
2007 & 199 & 885 & $23 \%$ & 6 Quota +1 \\
2003 & 54 & 765 & $7 \%$ & 6 Quota \\
1997 & 17 & 510 & $3.3 \%$ & None \\
1993 & 3 & 534 & $0.6 \%$ & 1 by Competition \\
1989 & 12 & 647 & $1.85 \%$ & None \\
\hline
\end{tabular}

The table shows that women's representation in the Chamber of Deputies is weak. Only three women succeeded in being elected to parliament through normal election, while the others arrived through the "Women's Quota", which indicates the serious weakness of women's political role in the Jordanian Chamber of Deputies.

In brief, in the elections of 1989, 1993, 1997, 2003, 2007, 2010, no woman succeeded in winning the elections through the nomination of a political party, except once in the 2003 election, namely Ms. Hayat Al-Musaymi in the first electoral district in Zarqa based on the nomination of the Islamic Action Front ${ }^{34}$.

Undoubtedly, the electoral law that is named "The one vote Law" which has been in effect since 1993 until the present time, is considered one of the impediments to real political participation, not only for the Jordanian woman, but for all the other forces in the country. For this reason, the slogans of Jordanian demonstrations and sit-ins called for changing of this Law, and the enactment of a modern and democratic law $^{35}$.

33. Jordanian Chamber of Deputies data: http://www.absoluteastronomy. com/topics/Chamber_of_Deputies_of_Jordan. See also Oraib Al-Rantawi, "Women and elections 2010: Facts and Figures", Addustour newspaper, Amman, 15, November, 2010.

34. http://archive.electionsjo.com/Esubject/DefaultSub.asp?seid=177

35. Al Shalabi Jamal, "Jordan: Revolutionaries without a Revolution", Révoltes arabes: premiers regards, Confluence Méditerranée, L'Harmattan, n 78 Printemps, 2011, Paris, p. 97. 
As regarding women's participation in the Senate, it started in 1989 when one woman was appointed to the Upper Chamber. This participation rose to two women in 1993, three women in 1997, seven in the Councils of 2003 and 2007, and nine women in 2009, making 15\% of the Chamber ${ }^{36}$.

It should be mentioned that according to Article 64 of the Jordanian Constitution, a member of the Senate "should be 40 Gregorian Calendar years of age, and must belong to one of the following categories: prime ministers, current and former ministers, former ambassadors, acting ministers, speakers of parliament, Court of Cassation and Court of Appeal judges, religious and secular, retired officers, of the rank of brigadier general and above, former members of Parliament who were elected not less than twice, and individuals of similar characteristics who have the confidence of the people and who have served the nation and the homeland" ${ }^{\prime 37}$.

In fact, on comparison with international ratios of women's participation in the Senate, it appears that Jordan with $15 \%$, is close to the USA (16\%) and Britain (19.7\%). Jordan also holds $5^{\text {th }}$ place among Arab countries in the number of women in parliament, after Tunis, where the ratio of women in the Senate is $15 \%$ and Mauritania, which holds first place among Arab countries at $16 \%{ }^{38}$. It is clear that Jordanian women's participation in the Senate is better than in the Chamber of Deputies, which is a clear indicator that the government wants to raise the political role of Jordanian women by appointing more women in the senate, which is appointed by the king based on the recommendation of the government.

\section{The Executive}

Women participate in the Executive Authority through the position of minister in the Council of Ministers. According to the Constitution, this authority consists of the King, who exercises his powers through the Ministers; meaning that the king is the head of the executive authority, hence the importance of the minister and his/her role.

The first time that a woman reached this position, since the democratic transformation, was the appointment of Ms. Rima Khalaf as Minister of Industry and Trade in 1993, in the Cabinet of Prime Minister Abdul Salam Al Majali. This appointment is particularly important because it

36. Al-Jabri Rania, "Jordan occupies $5^{\text {th }}$ place among Arab nations in the proportion of women in parliament", Al Arab Al Yawm news paper, 28 November 2010.

37. Article 64 of the Jordanian Constitution.

38. Al-Jabri Rania, op.cit. 
was the first time that a woman had received such an important portfolio. One year later, Ms. Khalaf was appointed Minister of Planning, while the Ministry of Social Development was entrusted to Ms. Salwa Al Masri in 1995, the first time ever that two women had served in the same cabinet. Ms. Khalaf continued to serve in three successive cabinets after that (Kabariti, Al Majali, and Rawabdeh) until 2000.

In the cabinet of Prime Minster Ali Abul Ragheb, two women were appointed ministers, Ms. Ruwaida Al Ma'aytah and Ms. Tamam Al Ghoul in 2002. The number of women ministers reached a new high in the Cabinet of Prime Minister Adnan Badran in 2005, with five women being appointed to this position. The number dropped by one on the appointment of Prime Minister Ma'rouf AI Bakhit in 2006, to rise again on the appointment of Prime Minister Nader Al Dahabi in 2007, with the number of women ministers rising to four. It dropped again to two in the cabinet of Prime Minster Samir Al Rifai and rose again to three in the second cabinet of Prime Minster Al Bakhit in 2011 ${ }^{39}$. As for women's participation in diplomatic work, the first woman was appointed as ambassador at the Ministry of Foreign Affairs in 1970. Today there are two women serving as ambassadors in France and Italy.

Nonetheless, the question relating to the role of woman in the executive branch of government presents itself: could we conceivably see a Jordanian woman in the position of head of one of the important ministries such as the Foreign Ministry, the Ministry of Interior, the Ministry of Justice and others?

Regarding high positions in the Judicial authority, which is closely related to the Executive, 1995 was a crucial year for women's participation because that year saw the first appointment of a woman as judge. This opened the door for other women to join the judiciary and their number rose to 60 judges in 2010, from 48 in 2009, and 42 in $2008^{40}$. These numbers are simple when compared to the announcement made by former Jordanian Minister of Justice Ayman Odeh, who said that the number of women judges will reach $40 \%$ of all judges in the coming few years ${ }^{41}$.

39. The official website of the Jordanian Prime Ministry: http://www. pm.gov.jo/english/.

40. Hadain Samar, "The National Center for Human Rights: Violence against women continues to be practiced in all its forms", Al Rai Newspaper, Amman, 2 April 2011.

41. Al Rai Newspaper, Amman, 8 March 2009. 


\section{Political parties}

Political parties are an integral part of civil society, and they are linked to "political development". There cannot be true political parties without the participation of all the different segments of society, including women who constitute nearly half of the total population in Jordan.

Article 4 of the Jordanian Political Parties Law of 1992 states that: "Jordanians have the right to form political parties and to join them voluntarily in accordance with the provisions of the law"42. The following table shows the proportion of women in Jordanian political parties, which proliferated as soon as the democratic transformation was announced in 1989, and the proportion to the total number of founders, according to the statistics of the Ministry of Interior.

A careful reading of Jordanian women's participation in political parties in the next table shows that it is at the lowest level in comparison with some Arab countries, although the promulgation of the Political Parties Law, in 1992, allowed open political party action. Women's participation in the founding committees of political parties was $9 \%$ of total founders, and no Jordanian woman has ever reached the position of secretary-general of a political party ${ }^{43}$.

It may be noticed in this table that the Liberal Party attracted the most women as founders of a party at a ratio of $50 \%$, followed by the Jordanian National Party at a ratio of $43.5 \%$; while women's participation in leftist parties was low, as the Jordanian Leftist Democratic Party only got $0.3 \%$; and the same applies to nationalist parties, where the ratios of participation were very low, as the ratios for the Baath Party and the Progressive Arab Baath Party were $0 \%$. As for the Islamic current, the ratio of women who founded it reached only $3.5 \%$, while the ratio for the Jordanian Communist Party was $7 \%$.

42. See the "Jordanian Political Parties Law of 1992" in El-Dajani Mohamed \& El-Dajani Munther, op.cit., p. 503.

43. Al-Rabab'ah Ghazi, "Women's participation in political life", University of Jordan, Amman (2003), p. 55. 
TABLE 2: WOMEN'S PARTICIPATION IN THE ESTABLISHMENT OF POLITICAL PARTIES ${ }^{44}$

\begin{tabular}{|c|c|c|c|c|c|}
\hline Ratio & $\mathrm{F}$. & M. & $\begin{array}{l}\text { N. of } \\
\text { Founders }\end{array}$ & Political Party & $N$ \\
\hline $0 \%$ & 0 & 75 & 75 & The Jordanian Ba'th Arab Socialist Party & 1 \\
\hline $7 \%$ & 5 & 66 & 71 & The Jordanian Communist Party & 2 \\
\hline $3.5 \%$ & 11 & 301 & 312 & The Islamic Action Front & 3 \\
\hline $12 \%$ & 12 & 88 & 100 & Jordanian Democratic People's Party (HASHD) & 4 \\
\hline $2.5 \%$ & 4 & 154 & 158 & Al-Mustaqbal (Future) Party & 5 \\
\hline $5 \%$ & 5 & 89 & 94 & The Jordanian Democratic Popular Unity Party & 6 \\
\hline $8 \%$ & 5 & 54 & 59 & The Progress Party & 7 \\
\hline $0 \%$ & & 76 & 76 & Al- Ba'th Progressive Party & 8 \\
\hline $15 \%$ & 11 & 61 & 72 & The Arab Islamic Democratic Party (Duaa) & 9 \\
\hline $1.5 \%$ & 1 & 61 & 62 & The National Action Party (Haqq) & 10 \\
\hline $5 \%$ & 3 & 62 & 65 & The Jordanian Arab Constitutional Front Party & 11 \\
\hline $50 \%$ & 53 & 52 & 105 & Al-Ahrar (Freedom) Party & 12 \\
\hline $0.3 \%$ & 1 & 276 & 277 & The Jordanian Left Democratic Party & 13 \\
\hline $7 \%$ & 6 & 79 & 85 & The Arab Jordanian al-Ansar Party & 14 \\
\hline $15 \%$ & 16 & 90 & 106 & Jordan Peace Party & 15 \\
\hline $3 \%$ & 2 & 57 & 59 & Al-Umma (Nation) Party & 16 \\
\hline $6 \%$ & 4 & 63 & 67 & The Arab Land Party & 17 \\
\hline $4 \%$ & 41 & 909 & 950 & The National Constitutional Party & 18 \\
\hline $13 \%$ & 8 & 55 & 63 & The National Democratic Public Movement Party & 19 \\
\hline $6 \%$ & 4 & 60 & 64 & Jordanian Labor Party & 20 \\
\hline $7 \%$ & 4 & 56 & 60 & Jordanian Generations Party & 21 \\
\hline $0 \%$ & & 70 & 70 & Jordanian Arab New Dawn Party & 22 \\
\hline $8 \%$ & 18 & 218 & 236 & Jordan Nahda Party & 23 \\
\hline $7 \%$ & 4 & 53 & 57 & Green Party of Jordan & 24 \\
\hline $4 \%$ & 2 & 51 & 53 & Citizens' Rights Jordanian Movement Party & 25 \\
\hline $9 \%$ & 5 & 48 & 53 & Jordanian Communist Toilers Party & 26 \\
\hline $6 \%$ & 4 & 61 & 65 & Jordanian People's Committee Movement Party & 27 \\
\hline $26 \%$ & 14 & 39 & 53 & Jordanian Welfare Party & 28 \\
\hline $6 \%$ & 7 & 115 & 122 & Al-Wasat Islamic Party & 29 \\
\hline $17 \%$ & 9 & 43 & 52 & Arab Jordanian Party & 30 \\
\hline $16 \%$ & 10 & 52 & 62 & The Message Party & 31 \\
\hline $26 \%$ & 19 & 55 & 74 & Alahed Party & 32 \\
\hline $30 \%$ & 16 & 37 & 53 & Party for Justice and Development & 33 \\
\hline $20 \%$ & 10 & 41 & 51 & Freedom \& Justice party & 34 \\
\hline $43.5 \%$ & 57 & 74 & 131 & Jordanian National Party & 35 \\
\hline
\end{tabular}

44. Al Shalabi Sohaila, "The Jordanian woman and political parties", Master's thesis, Al Beit University, Mafraq, 2004, p. 2. See also Alquds Centre for Studies, http:/www.alqudscenter.org/arabic/pages.php?local_type $=125 \&$ local_details=2\&id $1=103 \&$ menu_id $=30$. 


\begin{tabular}{|c|c|c|}
\hline Proportion & No. of Women Founders & Total Number of Founders \\
\hline $9 \%$ & 372 & 4,116 \\
\hline
\end{tabular}

Nevertheless, through their participation in party political life, Jordanian women succeeded in acceding to important positions in the parties. Women became members of the Shura (consultative) Council of the Islamic Action Front and of the political desks of the Communist Party, HASHD (the Democratic People's Party), and the Popular Unity party. But women's participation in the activities of political parties is still below the level required, and much below the ambitions of women; because women's participation in political parties is the most important indicator of the level of their participation in political life. Furthermore, the rise of the number of women in political parties would help them accede to more advanced positions ${ }^{45}$. A recent report by the Jordanian National Commission for Women states that women's participation in political parties is still "slight", not exceeding $6.3 \%$ in $2005,7.5 \%$ in 2007, to stay at the same level in $2010^{46}$.

\section{Hindrances against women's participation}

There are a number of factors that continue to hinder women's active political role and their participation in public life. The hurdles overlap between the political, economic, and social. On the political side, the One-Man-One-Vote Law of $1993^{47}$, which was enacted to limit the role of the Muslim Brothers ${ }^{48}$ after their overwhelming victory in 1989, returned the electoral process to its tribal and familial framework. It is known that these traditional social structures prefer to support a man

45. http://www.aawsat.com/details.asp?section=53\&article=220699\&issu eno $=9226$.

46. Al-Sarayra Rania, "Women's organisations seek political conditions that help increase women's participation in political parties", Al Ghad Newspaper, Amman, 20 February 2011.

47. The One Vote Law: It restricts the voter to one vote. This principle was applied in Jordan since 1973, while the 1989 elections were held on the basis of several votes for each voter. In the shadow of the Jordanian tribal system, the voter is at a loss as to whether to vote for an electoral platform or to vote for persons to whom he has special links irrespective of program. See http://www.aljazeera. net/News/archive/archive?Archiveld=56923.

48. Al Shalabi Jamal, "The Muslim Brothers in Jordan: From Alliance to Divergence", op.cit., p. 129. 
than a woman candidate irrespective of qualification ${ }^{49}$. Moreover, the lack of maturity and stability of political participation of Jordanian society in general, whether by men or women, and women's lack of political experience in political work in particular, is a hindrance to women's proactive political participation, to say nothing of women's economic subservience to men because of their low participation in economic activity and men's ownership of scarce resources in society.

The effect of political and legal factors rises, owing to Jordan's traditional social structure that is marked by "paternal domination" which is supported by social, religious, economic, educational, and political institutions, which support traditional gender roles. Despite the changes in the functions of traditional units (such as the family or the tribe), these units continue to play a central role in resolving a number of political participation functions in favor of men, marginalising the role of women.

Without doubt the traditional and conservative "political culture" that prevails in Jordan depends on a system of values and traditions that draw a stereotype of women through social upbringing. Religious and social define what is appropriate or inappropriate in the roles of men and women: they define what is appropriate for women as caring for their children, husbands, and families, while what is appropriate for men is defined as assuming political and legislative positions. In addition, there is a "negative view" held by women against women, which is termed "women's jealousy" in the political field. The polls of the Jordan Center for Social Studies support the saying that: "woman is woman's worst enemy", by showing that the number of women who voted for women candidates did not exceed $11 \%$, even though women leaderships deny this statement ${ }^{50}$.

Women's failure in free competition with men in legislative and municipal elections is a clear indication that Jordanian society does not trust women's ability in political work, which is the domain of men as many members of Jordanian society claim. Although the Jordanian state uses a number of forms of "positive discrimination" to offset this failure through proportional representation for women in parliament (quota) or appointment to municipal councils and some political and leadership positions, this does not necessarily mean that women have sufficient power and authority, because these women lack the support of popular bases and public opinion. They also lack the support of

49. http://www.sigi-jordan.org/pages/index.php?news=2.

50. Haddadin Samar, "Jordanian poll: the ratio of women who voted for women candidates did not exceed 11\%", Al Rai Newspaper, 26 February, 2008. 
official and unofficial leaderships that affect the process of political participation $^{51}$, who do not aspire to the development of modernisation due to weak cultural, social, and religious pretexts.

\section{CONCLUSION}

The issue of women's political participation is not unique to Jordan; it touches nearly the whole Arab world. Statistics show that the ratio of working women on average does not exceed 25\%-30\%, although the number of university degree holders from this segment of society reached $70 \%{ }^{52}$ in 2007 . This issue is more crucial in Jordan because women constituted nearly half of the population of Jordan, or $48.5 \%$ in 2008, and the number of women who have the right to vote (over 18 years old) reached nearly 1.191 million, making up $51.2 \%$ of the total number of Jordanian voters in $2007^{53}$. Although Jordanian women's participation remains below ambitions, compared with some other Arab countries, Jordan has made considerable progress in realizing the political participation of women, owing to the Hashemite dynasty's continuous and strong support. Lebanese Dr. Fahima Charafeddine, in a study prepared for UNESCO in 2004, referred to this fact: "On comparing Lebanon, which is considered the Arab country most affected by the West and its traditions, with Jordan, which has only recently started the process of modernization, we find that there is no significant difference in the status of women between the two countries. Women in Lebanon have the same opportunities for education as men (...) and the percentage of women graduates surpasses that of men; yet women's participation in parliament does not exceed 2.3\%. Moreover, not a single Lebanese woman has reached the position of Minister ${ }^{54}$. Jordanian women, on the other hand, surpassed their Lebanese counterparts in political participation because of the difference in the nature of the political regime. In reality, Jordanians are appointed directly by the king, and by consequence, women have participated in political life thanks to him" ${ }^{\prime \prime 5}$.

51. Owemer Walid, op.cit.

52. Knidiri Mohamed, "Women in Arab societies: the case of Morocco", Options Méditerranéennes, n 87, CIHEAM, Montpellier 2009, p. 29.

53. Owemer Walid, op.cit.

54. Recently, Ms. Muna Efesh was appointed minister in the cabinet of Mr. Saad Al-Harriri, in 2009.

55. Charafeddine Fahima, "Savoir, culture, politique : le statut de la femme dans le monde arabe", Unesco, Paris, 2004, p. 2. 